INTERNATIONAL JOURNAL OF MULTidisciplinARY RESEARCH AND ANALySis

ISSN(print): 2643-9840, ISSN(online): 2643-9875

Volume 04 Issue 09 September 2021

DOI: 10.47191/ijmra/v4-i9-14, Impact Factor: 6.072

Page No.- 1286-1289

\title{
Euthanasia - Meaning, Types and Its Indian Framework
}

\author{
Sharvari Digambar Darekar ${ }^{1}$, Dr. Dinesh Naik ${ }^{2}$ \\ ${ }^{1}$ Assistant Professor, Department of Psychology, MES Abasaheb Garware College \& Research Scholar, Department of Psychology \\ Savitribai Phule Pune University. \\ ${ }^{2}$ Principal, Arts Commerce and Science College Lasalgaon Nashik \& Research Guide, Department of Psychology Savitribai Phule \\ Pune University.
}

ABSTRACT: Euthanasia refers to the act which shortens or terminates life painlessly in order to end suffering where there is no hope of recovery. This paper covers the meaning of Euthanasia differentiating it from suicide. It also gives insight about the different forms or practices of Euthanasia depending to the situation or circumstances prevailing India is a democratic country having different cultures practiced. Viewing different thoughts, practices and history of Euthanasia in cultures of Hindu, Muslim and Christianity gives the significance of Euthanasia in Indian framework.

KEYWORDS: Euthanasia, Mercy killing, suicide, forms of Euthanasia, Indian framework, Hindu, Muslim and Christianit.

\section{INTRODUCTION}

Every human being strives to live and achieve greatest height in their life. They wish to enjoy their life and build relationship with people around, before the death comes to them. Death is not termed to be positive, especially when it happens unnaturally. Everyone in the world desires to live rather than die. Though this entirely is true, still we get to hear about the cases of suicide. Hence there are people who along with the wishes of living also sometime wishes to die by using unnatural means of dying ${ }^{(1)}$. This is also termed as abnormal as wishing to die is way away from normal thoughts of normal human beings ${ }^{(1)}$. When we talk about the desire to die, there are also certain cases where the person's life is ended by others on the request of the deceased. This is mainly in the case of the people who are suffering from terminal illnesses or suffering pain which is beyond their capacity to bear. People call it as Mercy killing, which is also known as Euthanasia ${ }^{(1)}$. Euthanasia has become the controversial issue, as it talks about issues which are ahead of our fundamental rights, morals, values and beliefs of the people. It states that, people who are severely handicapped or are suffering terminal illness should have the right to choose to live or die, though the same don't apply to the people who are sufficient and with sound mind ${ }^{(1)}$.

\section{MEANING AND TYPES OF EUTHANASIA}

The word "EUTHANASIA" comes from two Greek words, "eu" which means "good or easy" and "thanatos" which means "death"

${ }^{(1)}$. Hence it means "good or easy death" (1). It is also known as "mercy killing" (1). It refers to act which shorten or terminate life painlessly in order to end suffering where there is no hope of recovery ${ }^{(2)}$. It is the act of ending one's life by a lethal injection or suspension of medical treatment ${ }^{(3)}$. Encyclopedia of 'Crime and Justice', explains euthanasia as an act of death which will provide a relief from a distressing or intolerable condition of living ${ }^{(1)}$.

According to the World Medical Association euthanasia means, "Deliberate and intentional action with a clear intention to end another person's life under the following conditions:

- The subject is a competent informed person with incurable illness

- Who voluntarily asked for ending his life

- The person who is acting knows about the state of this person and about his wish to die and is doing this action with an intention to end life of this person

- The action is done with compassion and without any personal profit" (13) 


\section{Euthanasia - Meaning, Types and Its Indian Framework}

\section{TYPES OF EUTHANASIA}

\section{Active or Positive}

Active euthanasia is a deliberate action to end the suffering of the patient and painlessly putting them to death for merciful reasons ${ }^{(4)}$. Here the euthanasia is practiced actively by the doctor administering lethal dose or medication to the patient ${ }^{(1)}$. It is mostly found where the caretaker of the patient understands the suffering of the patient due to incurable disease and out of their love decides to release the patient from misery ${ }^{(5)}$. Active euthanasia is legally prohibited as compared to Passive euthanasia depending on the situation and the case ${ }^{(5)}$.

\section{Passive or Negative}

Passive or Negative euthanasia is speeding up the death by changing in the level and form of support offered to the patient ${ }^{(6)}$. This is in the view of letting the nature take its course in the death of the patient ${ }^{(6)}$. It is usually done by removing the treatment that was sustaining the life of the patient and hence the patient dies as a result of it ${ }^{(6)}$. It is passive as in the doctor is not actively killing the person; they are simply passively not saving the patient ${ }^{(7)}$. Simply practiced by removing life supporting device such as respirator or ventilator, stopping medications and medical procedures, removing the feeding tube, etc ${ }^{(6)}$. Sometime, when the patient is declared critical with no hopes to recover, the family members request the doctor to discharge the patient. The doctor discharges the patient on the request of the family and the patient dies in few days. Some family are not in a position to afford treating the patient and hence taken out of the ventilator. This is termed as an omission to struggle rather than an act ${ }^{(5)}$.

\section{Voluntary}

When the euthanasia is practiced directly with the consent of the patient on the request of the patient, it is called Voluntary euthanasia (1). It means the intentional administration of lethal drugs to terminate the pain suffered by the patient, the pain which is incurable and unbearable by the patient, that means the termination of life is thoroughly concerned on medical grounds (8). It is primarily concerned with the right of choice of the patient to end their life which in turn is beneficial for them and everyone else (1). In voluntary euthanasia, it is necessary that the request to end the life should be made by the person himself suffering from intolerable pain or terminal illness. This request should not be influenced or coerced by any family members or their caretakers around (5). The idea of voluntary euthanasia is based on the principle of self-determination and right to self-autonomy which talks about value, worth, respect, rights, freedom and decision making capacity (5). If an individual has decision making capacity, he also has the right to take decision on how and when he shall die. Refusing voluntary euthanasia is a form of domination, as the person is not respected for their views and being controlled by others (9). Voluntary euthanasia is also based on the Utilitarian principle. The purpose is to let the patient die peacefully and end the pain. It will be cruel to let people suffer the unbearable pain and hence the patient should be released of the pain ${ }^{(5)}$. Though this act is legally wrong but morally it is right.

\section{Involuntary}

In Involuntary euthanasia, the patient is not in the condition to request for ending their life, here the patient's life is brought to an end without their personal wishes or request ${ }^{(5)}$. The motive is to release the patient from suffering pain and terminal illness but without any request or decision from the patient to end their life ${ }^{(5)}$. This case is mostly when the patient loses all physical and mental functioning leaving only their biological body alive. Somewhere there is no hope of recovery of the patient in this case. Involuntary euthanasia is also based on utilitarian principle, promoting social welfare ${ }^{(5)}$. This is only done when the person is incapable of making own decision. The aim is to provide social benefits rather than more harm to the patient and caretakers around ${ }^{(5)}$. The individual who is suffering from persistent suffering and incurable disease and who wants to die but are unable to do so, they would be able to do it with the assistance of a doctor injecting dosage of drugs, though there are various cases against doctor charging them for murder or shortening the patient's life ${ }^{(5)(10) .}$

\section{Non-Voluntary}

Non-Voluntary euthanasia is ending the life of a person who is not in the position to request or is not mentally competent to take decision of ending his life ${ }^{(1)}$. Hence it involves someone else to take decision for the patient whether to end the patient's life. This decision is mostly taken by their close family members ${ }^{(1)}$. This is mostly done when the patient is completely unconscious or incapable of doing anything and when the patient has left no wish to live or given any further directions of living his life. It may be because of no opportunity to do so, or may have never anticipated such accident in their life ${ }^{(1)}$. 


\section{Euthanasia - Meaning, Types and Its Indian Framework}

\section{EUTHANASIA IN INDIA}

If we glance to the history of India, we would see a lot of instances where the right to die or end one's life was known to people and was practiced amongst human civilization ${ }^{(1)}$. In ancient Greece and Rome time, Euthanasia was a common practice as people helped others to die, mostly in the cases of severe birth defects and elderly people with pain and sufferings ${ }^{(1)}$. Many ancient texts or the holy book has mentioned about suicide or self-harm. The history of Vedic age in India has also mentioned about suicides committed on religious grounds. The common example of Suicide committed by Sati has been followed throughout by all the females after the death of their spouse. Ramayana, the famous holy writings also has witnessed the suicide of Sita. Similarly, Mahabharata and other religious writings have witnessed the suicide or decision of death taken by an individual them ${ }^{(1)}$. Most people believe that the doctor should not accept the request of death from the patient or anyone, as it disturbs the natural death process. They believe the soul and body gets separated in unnatural time, going against the nature, which then damages the karma of both the patient and the doctor ${ }^{(1)}$. Ancient people also believe on the teaching of Ahimsa which means not doing harm to anyone. Somewhere Euthanasia is against ahimsa and hence it should not be followed ${ }^{(1)}$. However, some group of people also believes that by helping the person to end their suffering and painful life is a good deed which fulfills the moral obligations ${ }^{(1)}$. As mentioned in Manu script, there was the practice of Mahaprastha or Renunciation, where the person suffering from incurable disease or who meets with a great misfortune start with a journey of departure which at the end result into death of that person ${ }^{(12)}$.

Knowing Euthanasia in India requires observing the belief system and practices followed by different cultures especially Hindu, Muslim and Christianity.

\section{Hindu culture:}

In Hindu culture, the teaching is to respect all forms of life and an unfavorable attitude towards killing anyone; hence the practice of Euthanasia was not accepted in the society ${ }^{(11)}$. The Hindu culture believes that the person who is suffering pain has to wait till the right time come for their death ${ }^{(11)}$. The caretakers should reduce the pain and suffering, but has no right to end anyone's life ${ }^{(1)(11)}$. The person who suffers is serving their karma as the suffering is the consequence of negative behavior ${ }^{(11)}$. The person is required to be calm at this stage of their life and face the suffering with the aim of moving towards liberation or moksha ${ }^{(11)}$. As discussed earlier the teaching of Ahimsa is strong rooted in Hindu culture, hence Euthanasia being against ahimsa is not accepted in the culture ${ }^{(1)(11)}$. However, there is a practice called as Somnvasi, where the person who is old and weak, wait till the death arise by refusing the intake of food and water; and prepare for their own funeral rites ${ }^{(11)}$. We have earlier mentioned of Sati which was thoroughly followed by the Hindu culture. They believe that the women who burn herself with her husband body on the funeral receive the status of goddess and become the ideal female ${ }^{(1)}{ }^{(11)}$. Some suicide was committed after the death of their loved ones as a mean of self-punishment for the crime committed ${ }^{(11)}$.

\section{Muslim Culture:}

In Muslim culture, the belief system follows that it is an individual's responsibility to take care of their health and seek immediate medical intervention whenever need arises ${ }^{(11)}$. They also believe that if there are sufferings in the world, God has also provided with the capacity to find the cure or solution to it ${ }^{(11)}$. Hence the practice of Euthanasia is not supported in the culture, in fact it is considered as an act of violation and rebellion against God's nature ${ }^{(11)}$. There are other views which are followed and accepted by the people practiced as a defense of their faith. Laying their lives or becoming a suicide bomber for their faith and culture are considered as martyrs ${ }^{(11)}$. In technologically advanced societies, Euthanasia is practiced in the case of terminally ill patients by withdrawing the life-sustaining mechanisms, considering the family and community values ${ }^{(11)}$.

\section{Christianity Culture:}

Christian culture considers taking one's life a self-murder ${ }^{(11)}$. They also believe that the physician should not interfere with the patient's spiritual journey by hastening the dying process ${ }^{(11)}$. John Paul II (1993) in Veritatis Splendor convicted euthanasia as an "intrinsic evil" and later repeated it as an act of violation of the law of God. He added that no one is allowed for the killing of an innocent human being whether it be the fetus, new born baby, an adult or an old person even though they are suffering from an incurable pain or disease. He also added that no one is even permitted to ask for the act of killing for the self and others and neither they are allowed to give consent for such request (Declaration on euthanasia (CDF 1980). The authority itself should not support or permit such an action as life is a God's gift and practicing euthanasia is taking away the rights of the god and giving it to human person (Brown 2007, 252) ${ }^{(11)}$. The people in this culture respect the redemption provided by the death of Jesus and somewhere people should experience the value of suffering done by Jesus ${ }^{(11)}$. Human beings should find meaning in suffering and at the same time also alleviate it or find possible treatment method for it ${ }^{(11)}$. In some peoples' view allowing a person to die can be morally right as this act has an intention to relieve pain. The patient's wish and readiness for death must be considered 


\section{Euthanasia - Meaning, Types and Its Indian Framework}

(Kelly $1994,349 f)^{(11)}$. On the contrary some people have views that helping someone to die by the health practitioners or someone else should be morally wrong and be considered as an act of killing an innocent person (Kelly 1994, 350) ${ }^{(11)}$. On debate of this point some catholic moral theologians expressed that the distinction between killing and allowing a person to die is not sufficient to make all acts of Euthanasia morally wrong. This is then to be decided using proportionalism method weighing the good and bad consequences occurring from the action. Hence, according to the Christian moral demand, actively and mercifully assisting the process of dying rather than letting the person suffer in pain is acceptable (Kelly 1994, 350f) ${ }^{(11)}$.

\section{CONCLUSION}

There are different views in each culture and also different views of people within the culture. Though Euthanasia is morally justifiable, its practice is yet not legalized. In a recent judgments provided by the Supreme Court, Passive Euthanasia is legalized and permissible under supervision of law in exceptional circumstances, but yet other types of Euthanasia are not permitted under the law in India.

\section{REFERENCES}

1) Roy, Caesar. (2011). POSITION OF EUTHANASIA IN INDIA - AN ANALYTICAL STUDY. The Indian Journal of Criminology and Criminalistics. XXXII. 37.

2) Dr. Parikh, C.K. (2006). Parikh's Textbook of Medical Jurisprudences, Forensic Medicine and Toxicology. 6th Edition, Page 1.55. New Delhi, CBS Publishers \& Distributors.

3) Brody, Baruch. (1998). Life and Death Decision Making, New York; Oxford University Press.

4) Humphry, Derek, Dying with Dignity Understanding Euthanasia 68, New York: Carol Publishing Group, 1992.

5) Concept of Euthanasia and its various Forms Vis-À-vis State's Duty To Protect Life: An Analysis. Retrieved from https://shodhganga.inflibnet.ac.in/bitstream/10603/99062/8/08 chapter-2.pdf

6) Kenneth R. Stevens (2006) Emotional and Psychological Effects of Physician-Assisted Suicide and Euthanasia On Participating Physicians, The Linacre Quarterly, 73:3,

7) 203-216, DOI: 10.1080/20508549.2006.11877782Aruna Ramchandra Shanbaug v. Union of India, 2011(3) SCALE 298; MANU/SC/0176/2011

8) Joris, Gielen, et.al., "Religion and Nursing attitudes to Euthanasia and Physician Assisted Suicide" Nursing Ethics, vol.16, Iss. 3, May 2009, p. 304. http://www.porquest.umi.com/pqdweb, [accessed on 18/8/2009].

9) Harris, J., "Euthanasia and the value of life" in Keown, J., (ed.), Euthanasia Examined 6, U.K: Cambridge University Press, 1995.

10) H Palmer 'Dr Adams' Trial for Murder' (1957) Cri. L.R. 365.

11) Ziebertz, H.G. (2019). Euthanasia, Abortion, Death, Penalty and Religion -The Right to Life and its Limitations (Vol 4).

12) (Springer). Retrieved from https://doi.org/10.1007/978-3-319-98773-6

13) Laws of Manu, translated by George Buhler, Sacred Books of the East by F. Maxmuller (1967 reprint). Vol. 25, page 206

14) Shah, T. (2017, March 19). Euthanasia, its types, ethical and moral dilemma, arguments for and against, religious views, philosophical arguments and legal validity in different countries (PowerPoint slide 4). SlideShare.

https://www.slideshare.net/digitaltejas/euthanasia-types-arguments-for-and-against 